\title{
E-Customers Purchase Intention towards E-Banking Payment Systems in Gujarat State
}

\author{
Dr Vasudev A Modi \\ Professor, Department of Commerce Maharaja Krishnakumarsinhji Bhavnagar \\ University, Bhavnagar \\ Email-vmodi@mkbhavuni.edu.in
}

\begin{abstract}
Technology has led banks to grow and expand its reach to the underserved areas as well. It is now the spearhead for Banking, making it more convenient for the common man. Indian banks are putting in place a robust infrastructure to leverage the benefits of IT. Also, it helps them function in an organized and secure way. Accounts at any of the Clearing Banks with access to the EFT clearing system can be credited or debited. Currently, banks have focused on a number of IT products especially EFT (Electronic Fund Transfer) which is comprehensive, flexible and cost effective alternative to cash and paper payments. The large value electronic payment systems, viz., Real Time Gross Settlement System (RTGS) and the Retail Electronic Payment Systems, viz., National Electronic Clearing Services (NECS and ECS), National Electronic Fund Transfer (NEFT) and Card Payment Systems are the electronic payment systems available in India. The researcher therefore aims at examining the intentions of e-customers for availing the ebanking payment systems. Regression Statistic $\mathrm{R}^{2}$ is considered by the researcher to measure the impact of the factors which determine the Purchase Intention of the e-customers for EBanking Payment Systems.
\end{abstract}

Key Words: E-customers, E Banking Payment Systems, Purchase Intention, Impact Assessment.

\section{Introduction}

Information Technological changes have brought in a vertical and not so subtle product in Banking. There has been a radical shift from mass banking to Class banking thereby bringing a total change in the face of Banking. The major driving force behind the technological up gradation \& transformations in the Indian banking sector has been the financial sector reforms of the nineties, opening up of the economy and globalization. Moreover, arrival of foreign and private banks with their superior state-of-the-art technology has led to growing competition in the sector. This has brought in a win - win catch situation between Bankers and Customers. The computerization and use of technology in banks has helped in a number of ways. Minimized costs of operation, Minimized transaction costs for customers, improved customer services, overall efficiency, and improved front end are examples of such outcomes. This has brought in widening the gap between marginal benefits and costs in the technological enabled Indian 
Banking set up. In the mid-eighties RBI started promoting computerization and Management Information System (MIS) in banking to improve customer services, book keeping and to enhance productivity. Since then banks, along with the guidance of RBI, achieved various objectives, such as the introduction of MICR based cheque processing, implementation of the electronic payment system such as RTGS (Real Time Gross Settlement), Electronic Clearing Service (ECS), Electronic Funds Transfer (NEFT), Cheque Truncation System (CTS), Mobile Banking System etc. With the support of RBI, the Institute for Development and Research in Banking Technology (IDRBT) was set up in Hyderabad as a research and technology centre for the banking sector for excellence and advancement in technology. Knowledge, Awareness, ease of use, safety and security, cost of Internet banking, reluctance and lack of computer or Internet access can affect attitudes and perceptions about the ebanking payment systems and most important buying decisions.

\section{Literature review}

Sathye (2009) Defines adoption as "the acceptance and continued use of a product, service or idea." Mols et al. (2009) study reveals that the diffusion of electronic banking is more determined by customer's acceptance than by the seller offerings. O'Connell (2010) demonstrated that the explanation for slow growth of Electronic banking is caused by security concerns, lack of knowledge about availability of such a service, Electronic banking sites being not user friendly and the lack of access to computers or the Internet. In line with Wallis (2011) whose report states that new technology adoption by the majority of the customers depends mainly on awareness, ease of use, safety and security, cost of Internet banking, reluctance and lack of computer or Internet access are focused. Today, in India Price/costs is one of the major factors that influence the consumer adoption of innovation. Gupta (2012), Mazursky et al., (2013) identify "price" as a major factor in brand switching. Also, the Wallis Report (2014) states that for "consumers to use new technologies, the technologies must be reasonably priced relative to alternatives". Otherwise, the acceptance of the new technology may not be viable from the standpoint of the consumer. One of the major factors for adopting Electronic banking is the availability of access to computers/Internet (Sathye, 2009). The Wallis Report (2014) states “as the Internet becomes more widely accessible households will conduct their financial transactions over the Internet" this means that, the more widespread the access to computer/Internet the greater the possibility of use of Electronic banking payment system adoption. O, Connell (2010) state that lack of access to computers as one of the reason for slow adoption of Internet banking. There for, lack of access to computers/Internet might be one of the major hindrances of adopting Electronic Banking payment systems in India. Cooper (2017) identifies "ease of use" as one of the three important characteristics from customer's perspective for adoption of innovative service. Katz and Aspden (2017), and Mols (2018) suggested that it is crucial for the Internet to be easy to use to increase the adoption rate Electronic banking. The Wallis Report (2014) identifies that technological innovation "must be easy to use" to ensure customer take up or acceptance. Daniel (2018) identifies "ease of use" as one of the factors for customer acceptance in her study of electronic banking payment system. This means that for successful implementation of Electronic banking, commercial banks must ensure that the services are 
simple, easy and of sufficiently high quality to ensure customer satisfaction in order to maintain their customers. Daniel (2018) stated that there is a high level of customer inertia in changing their established banking arrangements. Sathye (2009) emphasized that customers, particularly the senior citizens, prefer personal interaction and that they have technology phobia.

Furthermore, adoption of new technologies often comes across a certain amount of resistance to change from present ways of operating. This means that unless such a need is fulfilled by the commercial banks, customers may not be prepared to change from present ways of operating. Adoption can be defined as the acceptance and continued use of a product, service or an idea. According to Rogers and Shoemaker (2016), consumers go through "a series of process in knowledge, conviction, decision and confirmation" before they are ready to adopt a new product or service. Hence it is necessary that the commercial banks offering this service make the customers aware about the availability of such a product and explain how it adds value relative to other products of its own or that of the competitors. The added value in electronic banking payment system, according to Trethowan and Silicone, (2018), was convenience, sales orientation and lower costs. Security is one of the very important factors in determining the decision of consumers to use Electronic banking. Cooper (2017) identifies "the level of risk" as an important characteristic from a consumer's perspective in the adoption of innovation. In a study ABF (1997) found that security concerns are keeping both consumers and bankers away from Electronic banking. Booz et al. (2017), reveals that security concern among customers was the top ranking obstacle for non-adoption of Electronic banking payment system. Apparently, Electronic banking payment system will not be adopted in India unless it is considered safe and secure by the customers.

\section{Research Objective}

To examine the impact of factors which signifies E-Customers Purchase Intention towards EBanking Payment Systems in Gujarat State

\section{Research Methodology}

The sampling process has been used for the study. The samples of the population (e-customers have been selected). The convenience sampling method has been used in the research. The sample size is of 384. The samples include the e-customers who use ebanking payment gateways / systems since five years across Ahmedabad, Baroda, Bhavnagar, Rajkot and Surat City of Gujarat State. For the research work the primary data have been used. The primary data have been collected from e-customers who use ebanking payment gateways / systems since five years across Ahmedabad, Baroda, Bhavnagar, Rajkot and Surat City of Gujarat State. For research purpose relating to the topic for collection of data from respondents the instruments used includes telephone, internet, questionnaire, interview, and mail. Survey and observation methods 
have been used for data collection in this research work. The topic of the research work is a theoretical topic and there is no need to have experiments.

\section{Research Analysis}

It describes the impact of factors which signifies E-Customers Purchase Intention towards EBanking Payment Systems in Gujarat State. Hence the regression technique is used to identify the impact. If the value of $\mathrm{R}^{2}$ statistic is more than 0.7 , then it is suggestive measure of significant impact.

\section{Results and Interpretations}

Table 1: Correlation \& Regression Summary Statistics

\begin{tabular}{|c|l|c|c|c|c|}
\hline $\begin{array}{c}\text { Sr. } \\
\text { No. }\end{array}$ & Dependent Variable & $\begin{array}{c}\text { Independent } \\
\text { Variable }\end{array}$ & $\begin{array}{c}\mathrm{R} \\
\text { Statistic }\end{array}$ & $\begin{array}{c}\mathrm{R}^{2} \\
\text { Statistic }\end{array}$ & Inference \\
\hline 1 & Purchase Intention & Awareness & 0.789 & 0.623 & $\begin{array}{c}\text { Strong Positive Correlation } \\
\text { \& Insignificant Impact }\end{array}$ \\
\hline 2 & Purchase Intention & Accessibility & 0.806 & 0.650 & $\begin{array}{c}\text { Strong Positive Correlation } \\
\text { \& Insignificant Impact }\end{array}$ \\
\hline 3 & Purchase Intention & $\begin{array}{c}\text { Cost/Price } \\
\text { Factor }\end{array}$ & 0.826 & 0.681 & $\begin{array}{c}\text { Strong Positive Correlation } \\
\text { \& Insignificant Impact }\end{array}$ \\
\hline 4 & Purchase Intention & Ease of Use & 0.842 & 0.710 & $\begin{array}{c}\text { Strong Positive Correlation } \\
\& \text { Significant Impact }\end{array}$ \\
\hline 5 & Purchase Intention & $\begin{array}{c}\text { Reluctance to } \\
\text { Change }\end{array}$ & 0.688 & 0.474 & $\begin{array}{c}\text { Moderate Positive } \\
\text { Correlation \& In } \\
\text { Significant Impact }\end{array}$ \\
\hline 6 & Purchase Intention & Security & 0.838 & 0.703 & $\begin{array}{c}\text { Strong Positive Correlation } \\
\& \text { Significant Impact }\end{array}$ \\
\hline
\end{tabular}

Source: Spss output

\section{Interpretation}

\section{Purchase Intention and Awareness}

The R-value: shows the direction and the strength of the correlation. The bigger the value the more significant it is. In this case, the Pearson correlation coefficient $(r=0.789)$ shows a very strong positive correlation between the variables under investigation. This means the null hypothesis is rejected. Thus there is significant relationship between purchase intention and awareness about ebanking payment systems. Further $\mathrm{R}^{2}$ statistic helps in explaining variance in the dependent variable (Purchase Intention). Based on the results the ( $\mathrm{R}$ square) value is 0.623. This means that the independent variable (Awareness) predicts the dependent variable (Purchase Intention) by 62.30, thus, leaving out $37.70 \%(100 \%-62.30 \%)$ unexplained. This means that null hypothesis is accepted. 
Thus there is no significant impact of awareness about ebanking payment systems on purchase intention of the e-customers across Gujarat State.

\section{Purchase Intention and Accessibility}

The R-value: shows the direction and the strength of the correlation. The bigger the value the more significant it is. In this case, the Pearson correlation coefficient $(r=0.806)$ shows a very strong positive correlation between the variables under investigation. This means the null hypothesis is rejected. Thus there is significant relationship between purchase intention and accessibility of ebanking payment systems. Further $\mathrm{R}^{2}$ statistic helps in explaining variance in the dependent variable (Purchase Intention). Based on the results the ( $\mathrm{R}$ square) value is 0.650. This means that the independent variable (Accessibility) predicts the dependent variable (Purchase Intention) by 65\%, thus, leaving out $35 \%(100 \%-65 \%)$ unexplained. This means that null hypothesis is accepted. Thus there is no significant impact of accessibility of ebanking payment systems on purchase intention of the e-customers across Gujarat State.

\section{Purchase Intention and Cost / Price Factor}

The R-value: shows the direction and the strength of the correlation. The bigger the value the more significant it is. In this case, the Pearson correlation coefficient $(r=0.826)$ shows a very strong positive correlation between the variables under investigation. This means the null hypothesis is rejected. Thus there is significant relationship between purchase intention and cost / price factor of ebanking payment systems. Further $\mathrm{R}^{2}$ statistic helps in explaining variance in the dependent variable (Purchase Intention). Based on the results the ( $\mathrm{R}$ square) value is 0.681. This means that the independent variable (Cost / Price Factor) predicts the dependent variable (Purchase Intention) by $68.10 \%$, thus, leaving out $31.90 \%(100 \%-68.10 \%)$ unexplained. This means that null hypothesis is accepted. Thus there is no significant impact of cost / price factor on purchase intention of the e-customers across Gujarat State.

\section{Purchase Intention and Ease of Use}

The R-value: shows the direction and the strength of the correlation. The bigger the value the more significant it is. In this case, the Pearson correlation coefficient $(r=0.842)$ shows very strong positive correlation between the variables under investigation. This means the null hypothesis is rejected. Thus there is significant relationship between purchase intention and ease of use factor of ebanking payment systems. Further $\mathrm{R}^{2}$ statistic helps in explaining variance in the dependent variable (Purchase Intention). Based on the results the ( $\mathrm{R}$ square) value is 0.710. This means that the independent variable (Ease of use Factor) predicts the dependent variable (Purchase Intention) by $71 \%$, thus, leaving out $29 \%(100 \%-71 \%)$ unexplained. This means that null hypothesis 
is rejected. Thus there is significant impact of ease of use factor on purchase intention of the e-customers across Gujarat State.

\section{Purchase Intention and Reluctance to Change}

The R-value: shows the direction and the strength of the correlation. The bigger the value the more significant it is. In this case, the Pearson correlation coefficient $(r=0.688)$ shows a moderate positive correlation between the variables under investigation. This means the null hypothesis is rejected. Thus there is significant relationship between purchase intention and Customer reluctance to change factor. Further $\mathrm{R}^{2}$ statistic helps in explaining variance in the dependent variable (Purchase Intention). Based on the results the ( $\mathrm{R}$ square) value is 0.474 . This means that the independent variable (Reluctance to Change) predicts the dependent variable (Purchase Intention) by 47.40 , thus, leaving out $52.60 \%(100 \%-47.40 \%)$ unexplained. This means that null hypothesis is accepted. Thus there is no significant impact of reluctance to change factor on purchase intention of the e-customers across Gujarat State.

\section{Purchase Intention and Security Concern}

The R-value: shows the direction and the strength of the correlation. The bigger the value the more significant it is. In this case, the Pearson correlation coefficient $(r=0.838)$ shows very strong positive correlation between the variables under investigation. This means the null hypothesis is rejected. Thus there is significant relationship between

purchase intention and security concern factor. Further $\mathrm{R}^{2}$ statistic helps in explaining variance in the dependent variable (Purchase Intention). Based on the results the ( $R$ square) value is 0.703. This means that the independent variable (Security Concern Factor) predicts the dependent variable (Purchase Intention) by $70.30 \%$, thus, leaving out $29.70 \%(100 \%-70.30 \%)$ unexplained. This means that null hypothesis is rejected. Thus there is significant impact of security concern factor on purchase intention of the ecustomers across Gujarat State.

\section{Conclusion}

Thus it can be concluded that the e-customers across five major cities of Gujarat state viz Ahmedabad, Baroda, Bhavnagar, Rajkot and Surat all signify their positive behaviour towards purchasing the services with respect to e-banking payment systems. The factors such as awareness, accessibility, cost / price factor, ease of use and security concern assertively signify the purchase intention of the e-customers. However the moderate correlation between purchase intention and Customer reluctance to change factor is being visible. Further two factors Ease of use and Security Concern has significantly influence the purchase intention of the e-customers for availing the e banking payment system services across five major cities of Gujarat state viz Ahmedabad, Baroda, Bhavnagar, Rajkot and Surat. 


\section{References}

1. Booz, Allen \& Hamilton (2017). Internet Banking: A Global Study of Potential, Booz, Allen and Hamilton Inc. New York, NY.

2. Cooper, R.G. (2017). Examining Some Myths about New Product Winners, in Katz, R., ed., the Human Side of Managing Technological Innovation, Oxford, pp. 550-560.

3. Daniel, E. (2018) Provision of Electronic Banking in the UK and the Republic of Ireland. The International Journal of Bank Marketing 17(2)

4. Gupta S (2012) "Impact of sales promotions on when what and how much to buy" Journal of Marketing Research, Vol. 25, November, pp. 342-55.

5. Katz J. \& Aspden, P (2017) Motivations for and Barriers to Internet Usage: Results of a National Public Opinion Survey. Internet Research: Electronic Networking Applications and Policy, 7(3), 170-188.

6. Mazursky D La Barbera, P and Aiello A (2018) "When consumers switch brands" Psychology and Marketing, Vol. 4, pp. 17-30.

7. Mols, N.P., Bukh, P. \& Nielsen, J. (2018) Distribution channel Strategies in Danish retail Banking. International Journal of Bank Marketing, 27(1), 37-47.

8. O'Connell, B. (2010) Australian Banking on the Internet- Fact or Fiction? The Australian Banker, (December), 212-214.

9. Rogers, E.M. and Shoemaker, F. (2016) Communications in Innovation, Free Press, New York, NY

10. Sathye, M (2009) Adoption of Internet banking by Australian consumers: An empirical investigation. International Journal of Bank Marketing, 17 (7), 324-334.

11. Wallis Report (2014), the Financial System Inquiry Final Report (Chairman: Mr Stan Wallis), AGPS, Canberra.

12. Marketing Research, An Applied Orientation by Naresh K. Malhotra, Pearson Education, ISBN - 81-7808-368-X

13. Marketing Research Concept and Cases by Donald R. Cooper, Pamela S. Schindler, Tata

Mcgraw Hill, ISBN-13: 978-0-07-060091-1

14. Research Methodology (Methods and Techniques) by C.R. Kothari, New Age International (P) Limited, Publishers, ISBN (13): 978-81-224-2488-12. 